\title{
7
}

\section{HISTORIOGRAFI GLOBALISASI BATIK MASA KOLONIAL DAN TANTANGAN GLOBAL ERA KONTEMPORER}

\author{
Nuning Y. Damayanti Adisasmito
}

\begin{abstract}
With regard to the long history of the creation of Batik Indonesia and its development, batik technique becomes one that is recognized as the world cultural heritage. UNESCO on October $2^{\text {nd }}$, 2009 recognized belonging of Batik to the nation of Indonesia which became world heritage, then October $2^{\text {nd }}$ at once also celebrated as National Batike Day. This is the work of many parties and government support. Batik is a product of indigenous culture of Indonesia, especially made by the people of Java Island, but now scattered centers of batik industry almost throughout the Indonesian archipelago, not only in Pekalongan, Solo, Yogyakarta, Madura, Tasikmalaya, Cirebon, Garut. This fact adds to the rich variety of Batik Nusantara.
\end{abstract}

Keywords: batik, creative economy, globalization, contemporary, modernization

\section{PENDAHULUAN}

Historiografi Globalisasi Batik Masa

Kolonial yang Mempengaruhi Seni Eropa

Pada akhir abad ke-19 Batik pernah menjadi trendMode dan mempengaruhi kesenian Eropa dan bahkan menjadi inspirasi seniman seniman dunia di Eropa. Ada catatan sejarah mengenai keberadaan batik di Eropa yang ditulis oleh tokoh tokoh Eropa dan mereka pernah menetap di Indonesia dimasa kolonial. Dalam buku yang ditulis Sir Thomas Stanford Raffles yaitu "History of Java" (London 1817) menggambarkan pengalamannya selama dia menjadi gubernur Jawa pada tahun 1811-1816. Dia sebagai orang Inggris pertama kali yang membawa benda-benda seni Indonesia ke Eropa, termasuk di dalamnya adalah tekstil Nusantara dan batik. Di Eropa Raffles dianggap orang yang pertama menulis mengenai batik dan teknik batik dengan sangat rinci secara komprehensif. Koleksi batik Nusantara milik Raffles, akhirnya diakuisisi pada tahun 1859 oleh British Museum.

Orang Eropa lainnya yang memperkenalkan batik pada masyarakat eropa adalah seorang Belanda yaitu E Van Rijckevorsel, tinggal selama empat tahun diIndonesia. Tahun 1873 kembali ke Belanda membawa koleksi tekstil Indonesia dan menghadiahkannya kepada Katedral yang kemudian menjadi Museum Voelkerkundemuseum di Rotterdam. Kemudian pada tahun 1883, Rijckevorsel mengadakan pameran batik tekstil Indonesia di Amsterdam,yang mendapat apresiasi dan antusiasme yang luar biasa masyarakat. Pameran ini sangat sukses dan mendapat kritik yang baik dan menjadi headline berita, sehingga dipublikasikan dalam buku. 


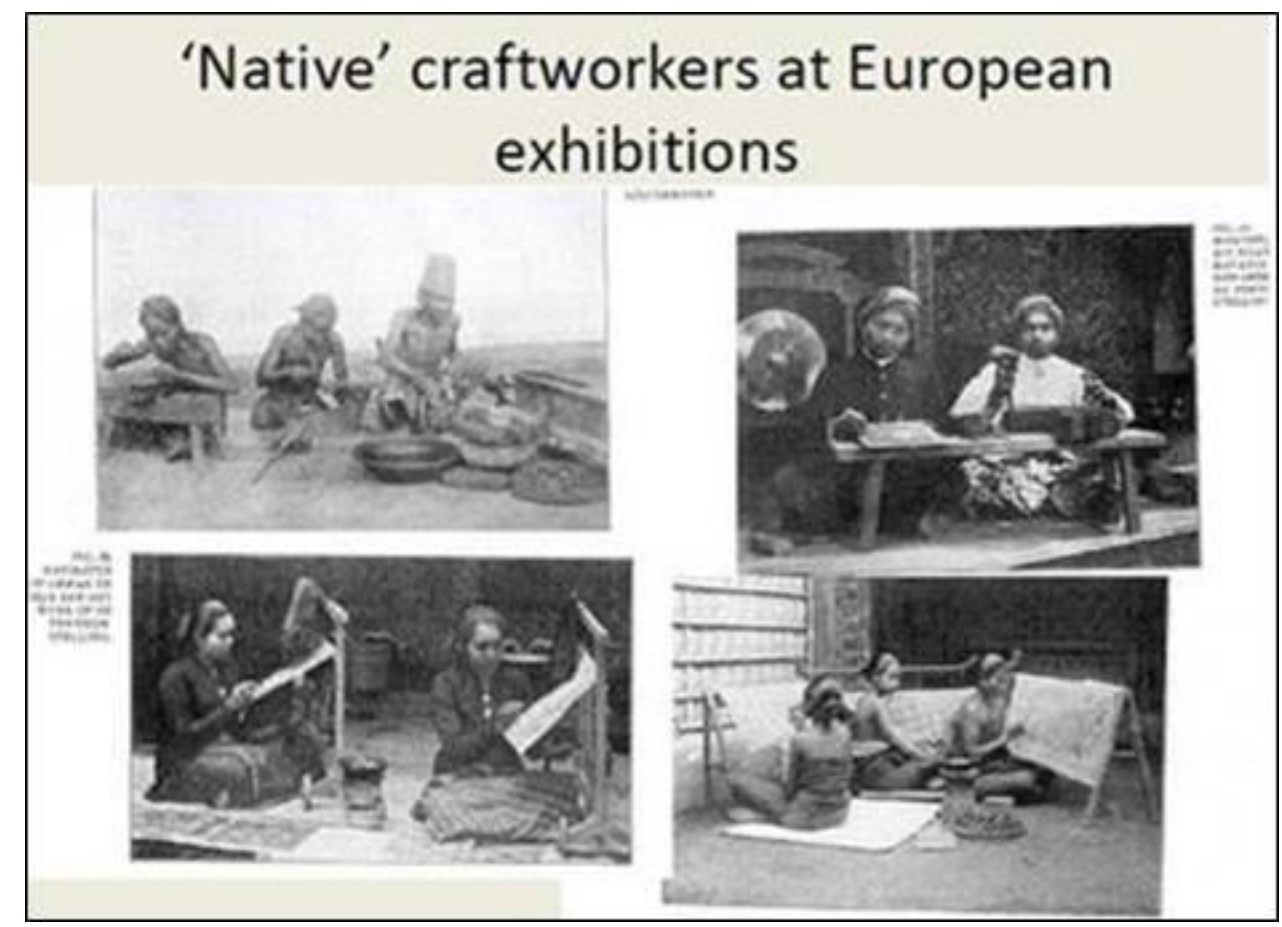

Pameran Teknik Batik dan demo membatik di Eropa masa kolonial Belanda

(by Pinterest | Javanese, Dutch east indies and

Yogyakarta, Tropen Museum Colection)

Pada tahun 1898 pameran batik kembali diselenggarakan di kota Denhag, saat itu pengunjung bisa melihat wanita pembatik yang memeragakan cara membuat batik. Pameran yang sangat mengagumkan, menjadi head line media massa dan tayangan yang menarik di Belanda. Tahun 1900 Pameran batik tingkat dunia digelar di kota Paris, dengan publikasi yang sangat baik, berkat pameran ini batik semakin dikenal oleh kalangan seniman, budayawan, penulis dan artis/aktor. Dalam berita dituliskan bahwa antusiasme dari apresiator dan kalangan seniman disamakan dengan reaksi antusiasmus beberapa tahun yang lalu ketika Seni Grafis Jepang dipamerkan di sana, yang kemudian sangat progresif mempengaruhi dan menginspirasi para seniman besar Eropa, bahkan menginspirasi sejumlah seniman Eropa, budayawan dan kalangan penulis di Prancis mempelajari kebudayaan Indonesia dikemudian hari diantaranya mengunjungi dan sebagian ada yang menetap di Indonesia.

Monografi tentang batik yang ditulis dan diterbitkan pada tahun 1900 G.P. Rouffaer dan Dr. H. H. Juynboll. Seni batik dipresentasikan dalam forum ilmiah di Museum kolonial Haarlem. Kemudian pada tahun 1901, bersama dengan Holandisch "East and west" Society, komunitas masyarakat Belanda Asing dan Timur, menyelenggarakan gelar pameran Tekstil dan Batik Indonesia di Haarlem. Antusiasme terhadap batik juga menyebar diJerman,awal Tahun 1900 diadakan pameran Tektil Tradisional di kota Krefeld, kota yang terkenal dengan tradisi tekstil Kuno di Jerman. 

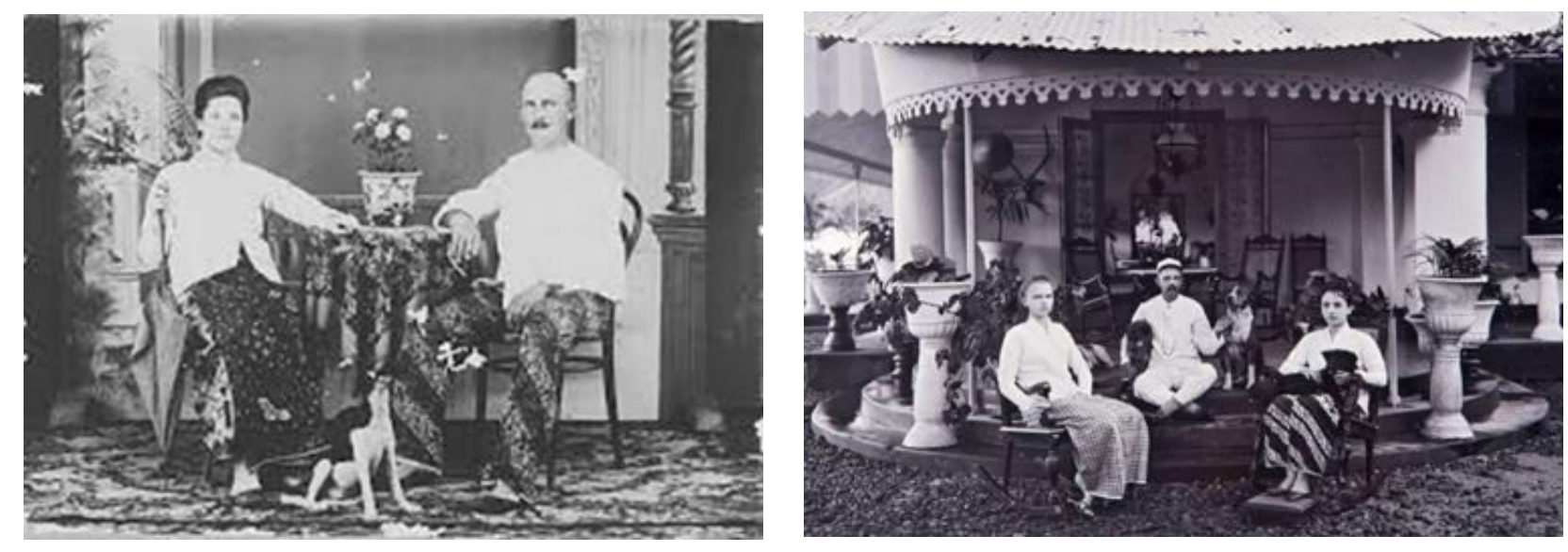

européen des Indes néerlandaises portant du batik (1900-1920)

(By Pinterest | Javanese, Dutch east indies and Yogyakarta, Tropen Museum

Colection)

Teknik batik dipelajari seorang seniman batik Belanda and pada tahun 1903 memamerkan batik kontemporer untuk pertama kalinya di Jerman. Pada tahun 1906 koleksi batik kontemporer yang dibuat dan disesuaikan dengan kondisi di jerman, Karya-karya batik itu dibuat untuk dikoleksi dan diklasifikasikan sebagai karya seni. Hingga masa Perang Dunia I dan II ketertarikan masyarakat Eropa pada batik masih tetap bertahan, tercatat pameran batik karya seniman Belanda dan Jerman terus diselenggarakan dikota-kota besar negara Eropayaitu tercatat dinegara Swiss, di Jerman, Belanda, Perancis, Inggris, Swedia dan Vatikan. Bahkan yang luar biasa adalah menjelang awal Perang Dunia II juga pameran Batik diselenggarakan di Amerika Serikat, Meksiko, Australia, di seluruh Asia dan juga diselenggarakan di Indonesia sendiri, di Jakarta, Bandung dan Yogyakarta.

Antusiasme terhadap batik dan tatacara memakai batik yang terjadi di Eropa berlangsung terus sejak awal abad ke-20, menjalar dengan cepat mempengaruhi tren dan motif fashion di Eropa pengaruh yang tidak terbayangkan terjadi terutama di Jerman, Perancis, Belanda dan Swiss. Salon-salon artis terkenal pada masa itu, dihiasi hiasan benda benda eksotis dari Timur dan Oriental di salon salon mereka kemudian diganti dan dipenuhi oleh nuansa Indonesia dan batik. Batik dan ragam motif kontemporer di masa itu juga muncul di studio-studio pelukis dan mempengaruhi dan menginspirasi seniman seniman kelas dunia diantaranya dapat ditelusuri pada karya Degas, Modigliani, Klimmt, Mucha, Rosseau, Edvard Munch, Kubin dan lainnya

Selain itu tren fashion batik juga dengan cepat menyebar secara spontan terefleksi sangat kuat pada gaya Art Nouveau dan gaya Jugendstile Eropa yang diterapkan terutama pada tekstilhingga paruh abad ke-20 yang masih dapat diamati jejak-jejaknya. Visualisasi batik perlahan meredup tergeser oleh kemunculan Gaya Art Deco. Antusiasme masyarakat Eropa terhadap batik dan "eksotisme" nya yang 
memesona pada pertengahan awal abad 20 di Eropa mulai hilang. Akan tetapi fakta sejarah menunjukan, batik meninggalkan jejak yang mendalam pada seniman-seniman Eropa, dengan adanya pengetahuan tentang batik yang tetap abadi tercatat dalam sejarah Eropa. Pengetahuan itu sampai sekarang bisa kita pelajari dan kita masih bisa berbagi untuk memahami catatan sejarah penyebaran Seni Batik di Eropa secara obyektif. Batik telah hadir dan mengglobal sejak lebih dari seratus tahun lalu.

\section{DASAR TEORITIS}

Batik Masa Kini, Wacana Kontemporer dan Globalisasi Industri Kreatif

Perkembangan batik di Indonesia pada era persaingan pasar global ini sangat bervariasi baik dalam desain, media, dan fungsinya.Desain batik yang bervariasi itu dapat berupabatik tradisional, batik modern, maupun kontemporer.Keragaman penciptaan produk dan motif batikmasa kini, hampir tidak dikenali lagi akar tradisi budayanya dari mana asal dan siapa pembuatnya.

Kreativitas penciptaan desainbatik modern semakin lama semakin beragam bentuk dan fungsinya. Di masa lalu produk batik masih bernilai sakral, fungsional,dan milik kolektif, sedangkan sekarang terjadi degradasi fungsi dan nilai pembuatan batik sudah bergeser menjadi produk yang bernilai konsumtif, ekonomis, dan individualis.

Seperti juga yang terjadi pada lingkup perkembanganseni rupa modern di Indonesia diungkapkan Soedarso Sp (2000), "Seni rupa modern masuk kepelosok Indonesia bagaikan air bah yang menerjang apa saja, juga tradisi warisan budaya bangsa. Segala macam ide dan faham asing yang muncul dari luar itu datang secara bertubi-tubidan bersamaan masuk ke wilayah Indonesia, sehingga menyebabkan kegamangan bagi masyarakat awam".Dari kenyataan itu, menunjukkan bahwasedang terjadi degradasi dan pergeseran budaya lama menuju budaya dan moralitas baru. Budaya dan moralitas baru tersebut sedang tumbuh dan berkembang dalam masyarakat kini danbergeser memudarkan budaya tradisi yang ada.

Menemukan batikyang dibuat dengan cara tradisional khas perdaerah dengan motif desainnya yang khas mulai langka. Pada umumnya desain batik dan motif kontemporer hanya cuplikan pengulangan dari motif lama atau bahkan meninggalkan motif tradisi asli daerahnya dan bergeser ke motif kontemporer, memenuhi selera masyarakat masa kini yang serba praktis dan instan. Keberagaman bentuk dan motif pesanan desain batik dari konsumen membanjiri perajin kita, kini di setiap provinsi mempunyai ciri khas masing-masing motif batiknya, demikian juga warna yang dipergunakan.

Kondisi sekarang ini, Takdir Alisyahbana mengatakan bahwa berbagai aspek kebudayaan berada dalam tahap krisis yang disebabkan oleh pertemuan budaya lokal dan budaya asing yang bercampur aduk saling mempengaruhi (Alisjahbana 1985:52). Dalam hal ini, jelaslah perkembangan ilmu pengetahuan dan teknologi jugabudaya asing di Indonesia yang progresif. 
Keseluruhan merupakan faktor-faktor yang sering menyebabkanperubahanfungsi, visualisasi produk budaya termasuk juga krisis melanda tehnik batik dewasa ini yang berkembang di masyarakat. Era globalisasi ditandai dengan perubahan -perubahan yang begitu cepat. Tentang kekawatiran para futurolog dengan perubahan jaman yang begitu cepat di era globalisasi,Soedjatmoko menyatakan bahwa kaum futurolog sendiri pada saat ini sudah tidak sanggup lagi meramalkan hari depan karena kompleksitas dunia cheossekarang ini. Apalagi meramalkan hari depan kesenian yang memang selalu meledak ledak (Soedarso SP., 1991). Adanya perubahan kebudayaan dan perilaku manusia dalam masyarakat dari keadaan tertentu ke keadaan yang lain. Menurut Gillin, perubahan sosial adalah suatu variasi dari cara-cara hidup yang telah diterima yang disebabkan karena perubahan lingkungan geografis, kebudayaan material, komposisi penduduk, ideologi, maupun karena adanya difusi atau pun penemuan baru dalam masyarakat (Abdulsyani, 1994:163; Hendropuspito, 1989:256). Budaya dan kebutuhan manusia terus berkembang seiring dengan perkembangan jaman dan tuntutan kebutuhan masyarakat. Demikian juga kebutuhan berkesenian secara umum. Hal ini menunjukan bahwa pemikiran, peradaban, kebutuhan terus berkembang untuk mencari dan menemukan kreativitas baru sesuai perkembangan kebudayaan, teknologi, dan seni. Dalam duniabatik dari fenomena itu lahirlah batik baru yang berangkat dari pemikiran postmodern hingga kontemporer.Munculnya visualisasi motif batik bernuansa primitif, bernuansa antik, bernuansa klasik, dan desain batik modern. Kreativitas baru dibidang batik ini mendapatkan perhatian khusus dari masyarakat konsumen dan pasar yang luar biasa baik di pasar lokal juga global.

Globalisasi yang dipandang sebagai globalisasi kebudayaan menurut Rohidi (2000) adalah suatu fenomena luasnya, mendunia, dan menjadi satuan kerangka acuan atau sistem gagasan tertentu yang dilandasi prinsip - prinsip pemikiran modern yang bertumpu pada ilmu pengetahuan dan teknologi yang sangat prestisius dilandasi oleh pemikiran yang bersifat positivistik. Lebih lanjut dikatakan bahwa globalisasi kebudayaan sebagai arus positif dipahami sebagai sebuah tatanan konsensus dilihat dari segi iptek yang mengubah dunia dengan ukuran produktivitas, penguasaan alam, dan penguasaan manusia lainnya, maka telah terjadi penindasan nilai- nilai spiritual dan tradisi yang bersifat pluralistik. Peradaban manusia mulai dari abad pertanian, abad industri kemudian abad informasi, terus bergulir dan teori-teori terus berkembang hingga saat ini peradaban manusia dengan kompetisi yang ganas dan globalisasi, masuk pada eraperadaban baru kita menyebutnya peradaban ekonomi berorientasi pada Kreativitas dan Knowledge based Economy.

Industri_kreatif dan Ekonomi Kreatif adalah istilah yang diperkenalkan oleh seorang multi profesi John Howkins, dalam bukunya "Creative Economy, How People Make Money from Ideas". Menurut Howkins, Ekonomi 
Kreatif adalah kegiatan ekonomi dimana input dan outputnya adalah Gagasan. Esensi dari kreatifitas adalah gagasan.dengan modal gagasan, seseorang yang kreatif gagasan yang orisinil dan dapat diproteksi oleh HKI (dalam Nenny, 2008).Robert Lucas seorang pemenang Nobel di bidang ekonomi, mengatakan bahwa kekuatan yang menggerakan pertumbuhan dan pembangunan ekonomi kota atau daerah dapat dilihat dari tingkat produktifitas klaster orangorang bertalenta dan orang-orang kreatif atau manusia-manusia yang mengandalkan kemampuan ilmu pengetahuan yang ada pada dirinya ( Nenny, 2008).Teori Industri Kreatif , sementara ini Kementerian Perdagangan Indonesia menyatakan adalah industri yang berasal dari pemanfaatan kreativitas, keterampilan serta bakat individu untuk menciptakan kesejahteraan serta lapangan pekerjaan dengan menghasilkan dan mengeksploitasi daya kreasi dan daya cipta individu.

\section{HASIL KAJIAN DAN PEMBAHASAN}

\section{Tradisi dan Desain Batik Kontemporer di}

\section{Era Globalisasi}

Batik diciptakan dan sudah memasyarakat sejakberabad-abadselaras dengan perjalanan sejarah bangsa Indonesia, batik merupakan salah satu teknik yang diterapkan pada tekstil di Indonesia, menjadi karya seni yang telah mengglobal dan sekarang tidak hanya ditemukan di Pulau Jawa dan Indonesia saja tetapi juga beberapa negara lainnya, sejumlah negara Asia dan Afrika khususnya. Di Indonesia setiap daerah mengembangkan dan memiliki motif batik dengan kekhasan dan keistimewaan masing-masing. Batik dimasa kini tidak hanya dipergunakan sebagai sandang untuk kegiatankegiatan tradisi saja. Batiksemakin berkembang mengalami modernisasi dalam berbagai aspek terkait fungsi dan tujuan penciptaannya. Batik diterapkan dalam benda-benda keseharian yang berfungsi mendukung kebutuhan masyarakat pendukungnya menyesuaikan diri dengan pemikiran dan budaya kontemporermasa globalisasi kini.
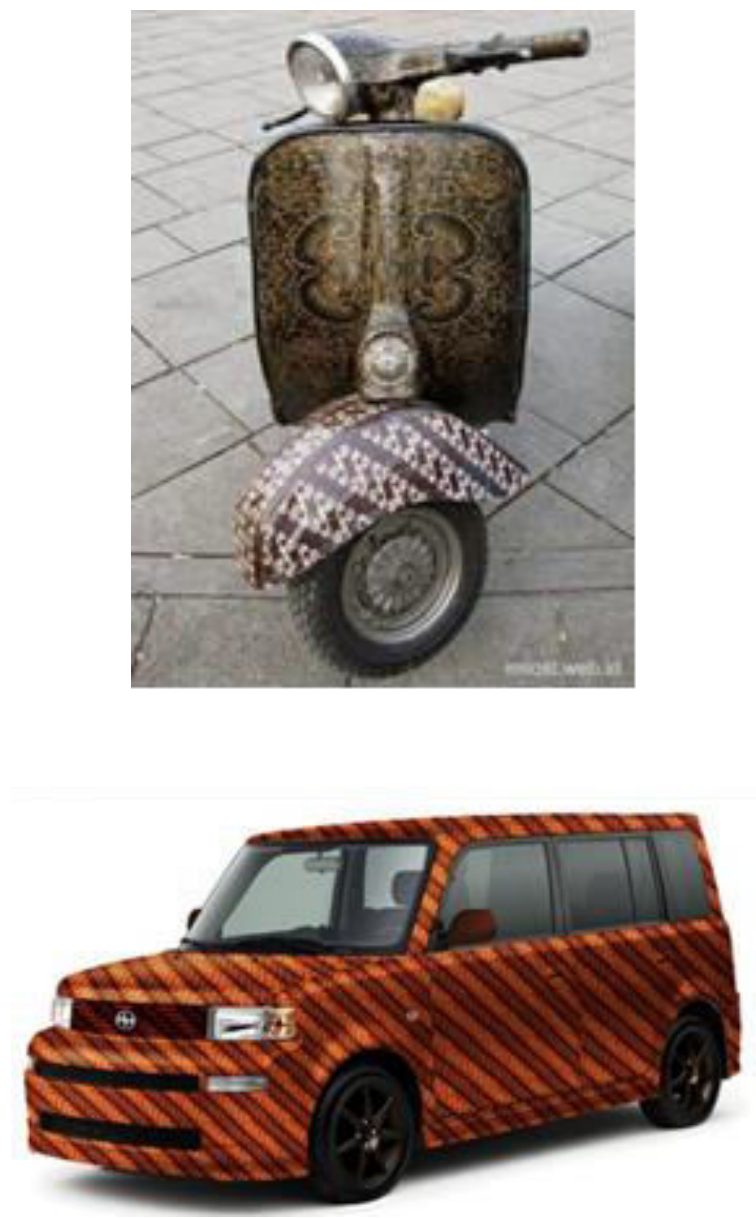

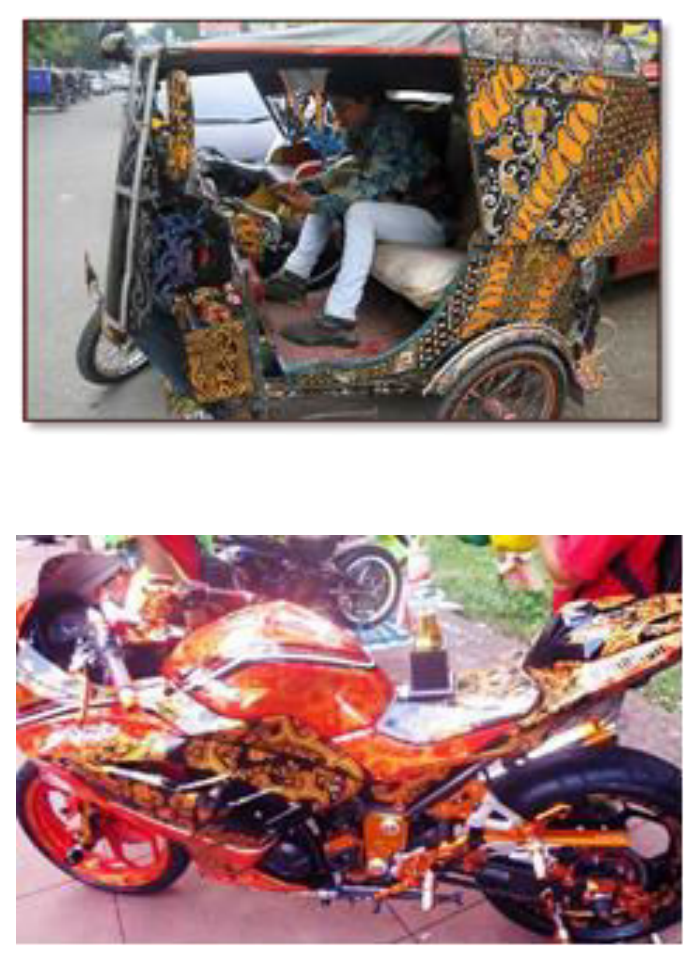

Motif Batik diterapkan pada benda keseharian : alat transportasi

(https://pridesonline.wordpress.com/2009/12/ 31/transport.motif-batik/

Akhir-akhir ini terlihat gejala munculnya kembali desain batik tradisional sama derasnya dengan gejala perkembangan desain batik modern permintaan pasar global. Pengaruh globalisasi telah merambah di segala sektor dalam kehidupan masyarakat.Suatu masyarakat yang dulu dikenal memiliki kekayaan dan keragaman budaya tradisi dari sedikit mulai bergeser menuju perubahan baru karena pengaruh modernisasi. Dalam masyarakat yang mengalami pergeseran ini tentunya terjadi konflik- konflik kepentingan yang tak dapat dielakan lagi. Suatu pemikiran untuk tetap melestarikan budaya tradisi berhadapan dengan tuntutan baru harus menerima budaya baru yang menjanjikan kemudahan, kenikmatan, lebih bergengsi, mudah dinikmati, dan sekaligus membuat ketergantungan masyarakat. Sehingga ada pernyataan banyak orang kalau tidak ikut dalam perkembangan budaya baru akan ketinggalan dengan perubahan tersebut. Kalau ikut dan larut dalam perkembangan baru tersebut banyak yang kebingungan, lebih- lebih mereka yang tidak memiliki dasar pijakan budaya yang kuat dan mendasar.

Sementara banyak kalangan menyatakan bahwa kesenian tradisional tidak berubah tetap berpegang pada kaidah dan tata aturan baku dari waktu ke waktu secara turun temurun. Kenyataanya walaupun tidak secepat seni modern batik tradisional juga secara gradual berkembang mengikuti perkembangan jaman sesuai lahannya masing-masing.Desain batik tersebut, baik yang diciptakan desainer maupun atas permintaan konsumen. Bagaimanapun juga kalau masyarakat berkembang kebudayaan juga ikut berkembang sesuai irama perubahan jaman. Perubahan dan perkembangan itu membawa seni batik bermunculan kembali dengan berbagai warna, bentuk, dan tujuan. Era otonomi daerah yang sekarang sedang berjalan adalah era di mana munculnya kebangkitan seni tradisi di tiap daerah. Semua daerah otonomi mulai mendata dan mencermati potensi daerah untuk diangkat dikelola dan dikembangkan sebagai aset daerah di masa depan. Kesenian tradisional di dalamnya batik bermunculan kembali untuk menyongsong era pasar global. Batik bernuansa etnik bermunculan kembali dengan wajah dan bentuk baru kebanyakan orang menyebut batik modern dan kontemporer. Percepatan globalisasi dunia juga 
mengakibatkan terjadinya berbagai perubahan perilaku masyarakat di segala lapisan. Perubahan tampak jelas pada kebutuhan akan perumahan, pakaian, makanan, barang luks dan sebagainya. Perubahan nilai atau norma sosial, ekonomi, politik yang berpengaruh terhadap perdagangan internasional. Demikian juga di produksibatik ikut berubah dan berkembang pesat desain batik baru atau modern sesuai kreativitas seniman, desainer dan tuntutan pasar.

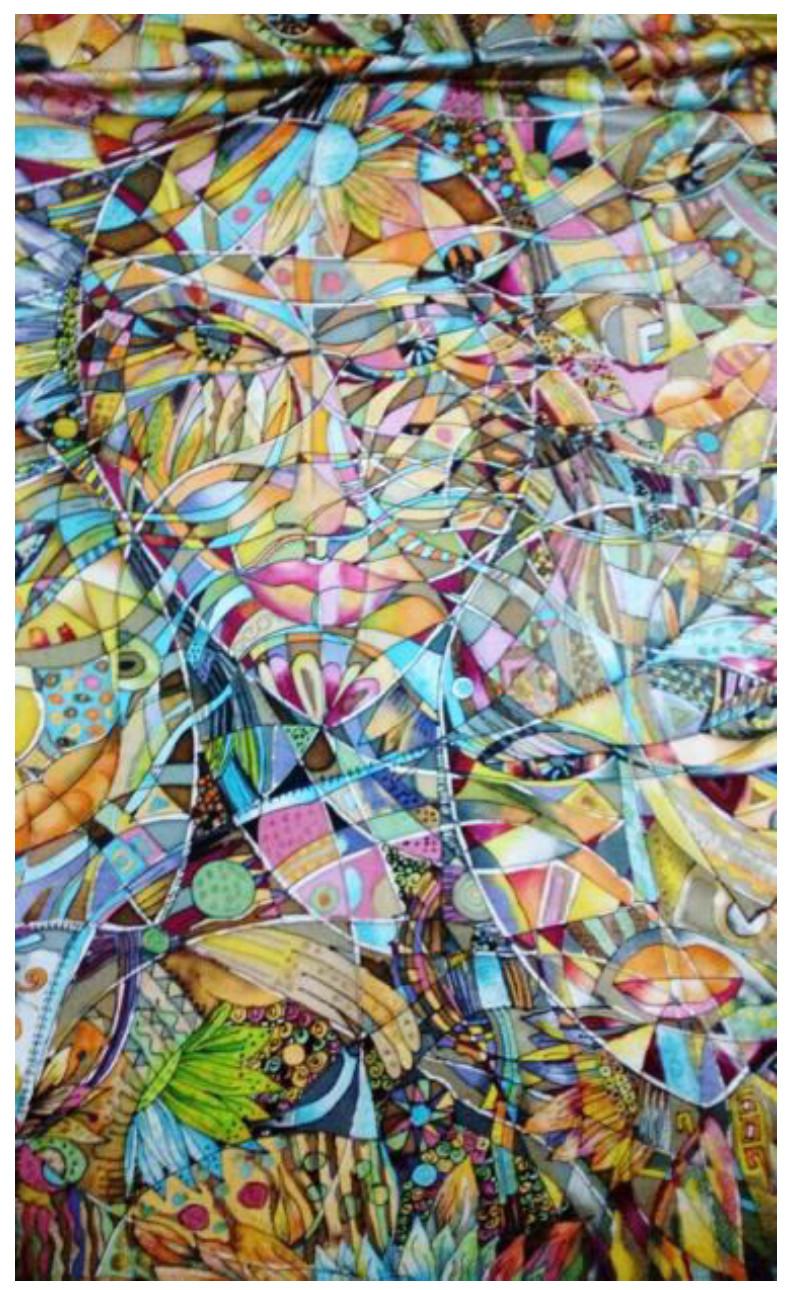

Lukisan Batik Motif Wajah-wajah (Karya Enes, 2016)

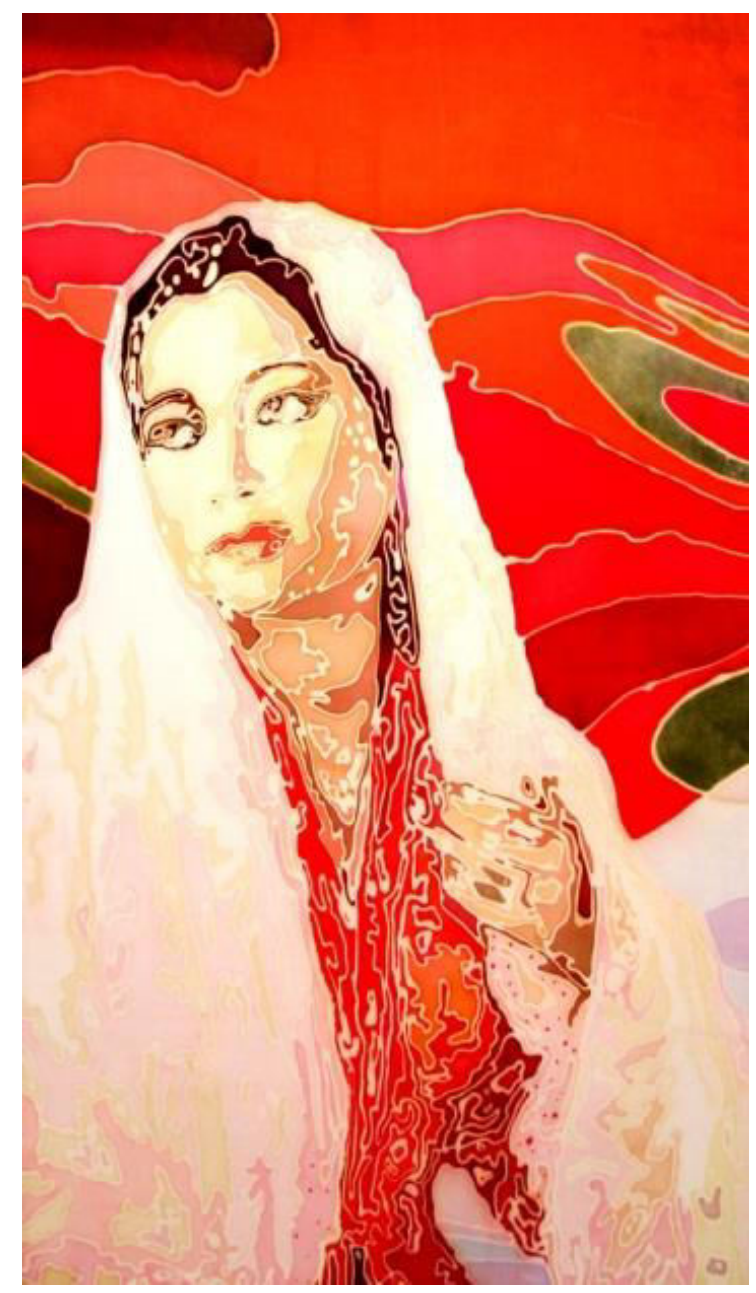

Lukisan Batik, Figur Fatmawati

( Karya Nuning Damayanti, 2017)

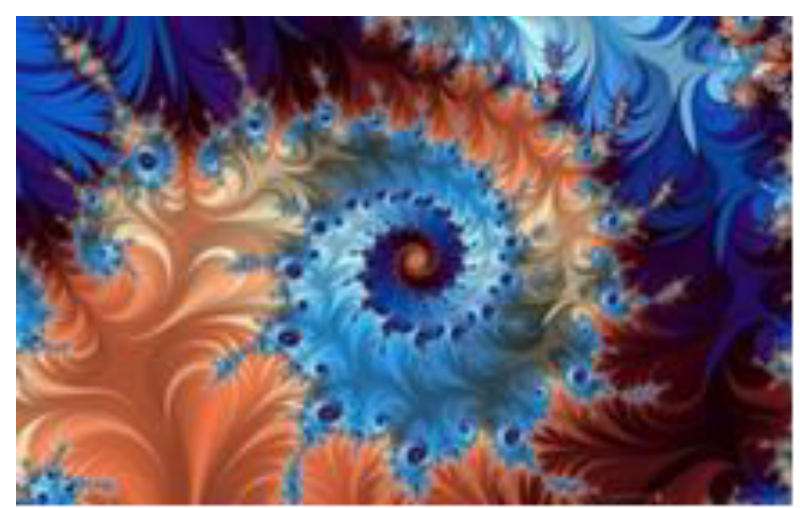

Lukisan Batik Kontemporer Fraktal (http://glo-batik.blogspot.co.id/2016) 


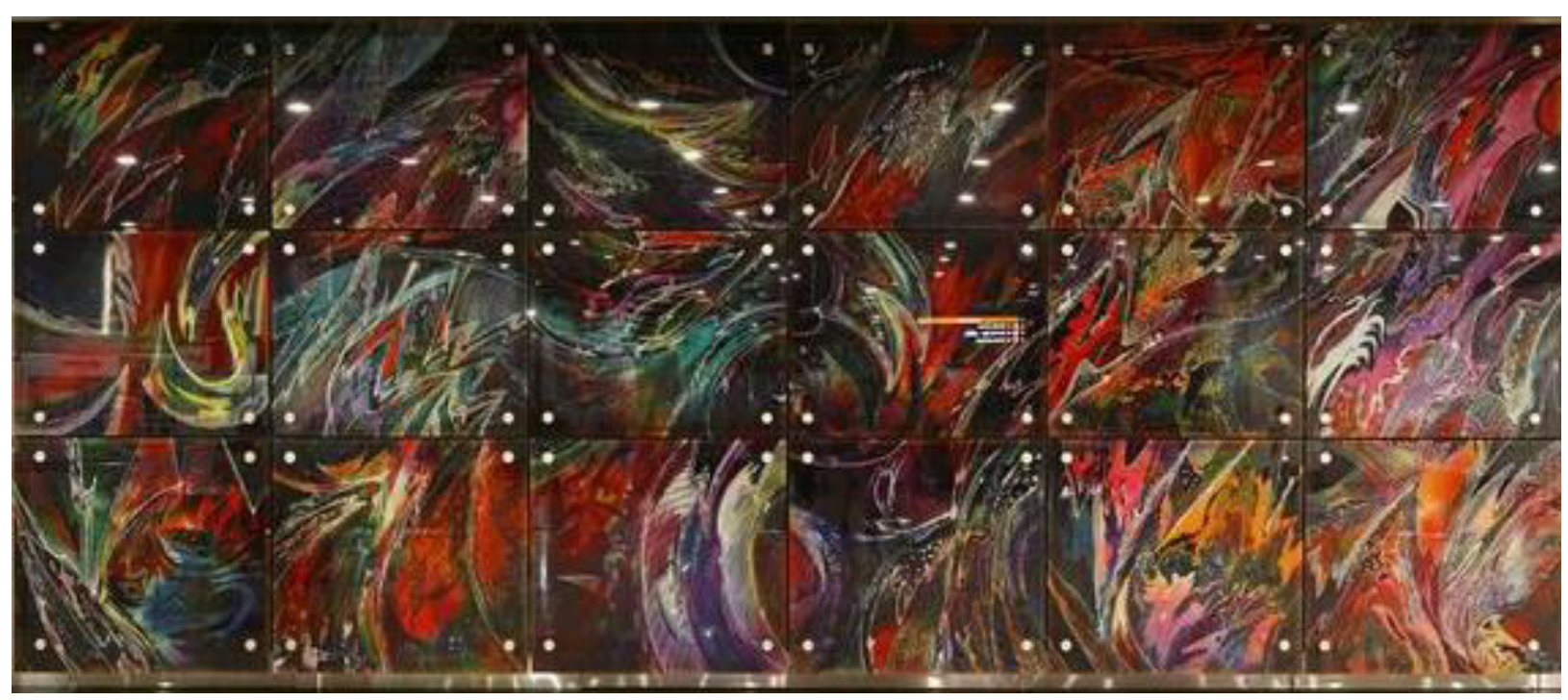

Mural Batik Motif Abstrak (uk. 2,4X6 m)

Pameran batik Kontemporer, Galeri NUS Singapore 2013

Kebudayaan akan berkembang terus sesuai dengan perkembangan jaman, ilmu pengetahuan dan teknologi serta kepandaian manusia. Pada abad keterbukaan ini pengaruh budaya luar begitu derasnya, maka akan secara langsung maupun tidak langsung berpengaruh terhadap keberadaan budaya lokal sendiri. Globalisasi jika diartikan sebagai penyebaran budaya tradisional keseluruh penjuru dunia dengan menerobos batas batas aturan tradisional berdasarkan kelompok suku, agama, adat sesungguhnya merupakan fenomena yang wajar dari kehidupan bersama dalam interaksi dengan dunia luar. Tetapi globalisasi yang didorong oleh kemajuan informasi yang menyebabkan komunikasi semakin bebas tak terbatas, menyebabkan kelunturan budaya, egoisme baru, akhirnya kehilangan identitas baru merupakan persoalan identitas bangsa yang perlu dicermati bersamaProses yang demikian itu perlu diantisipasi oleh generasi penerus melalui proses pendidikan atau proses pembudayaan yang lainnya. Sejalan dengan itu seperti yang dikemukakan Kneller (dalam Pidarta, 1997) bahwa dalam pengembangan kebudayaan meliputi tiga unsur, yaitu ; originalitas mengandung kebaruan, difusi budaya perpaduan/modifikasi, reinterpretasi pemaknaan ulang akibat perubahan zaman.

Pemikiran inilah yang berkembang dan dimanfaatkan oleh para desainer/pengrajin batik di Indonesia. Sejalan dengan pemikiran itu, harus dilakukan proses pembelajaran sebagai cara untuk pengembanganbatik modern,hal tersebut ada beberapa strategi dengan cara ; Meniru desain tanpa perubahan, Merubah desain secara inovatif dan Menciptakan desain batik baru.

Banyak kekhawatiran akan kehilangan jati diri kebudayaan terjadi akibat ditelan pengaruh budaya global. Rahman (Pidarta,1997) menawarkan solusi dan pembaharuan agar 
kesenian kita tidak tergeser oleh kesenian global.

Kesenian kita tidak boleh hanya sebagai objek kesenian global melainkan harus dapat menjadi subjek kesenian yang dapat menentukan dirinya sendiri. Cara menjadi subjek adalah kemampuan menciptakanunggulan, karya besar yang sanggup memberi sumbangan kepada kesenian dunia. Suatu karya seperti hasil kreativitas leluhur kita menciptakan kesenian tradisional adiluhung yang tidak lekang oleh zaman.

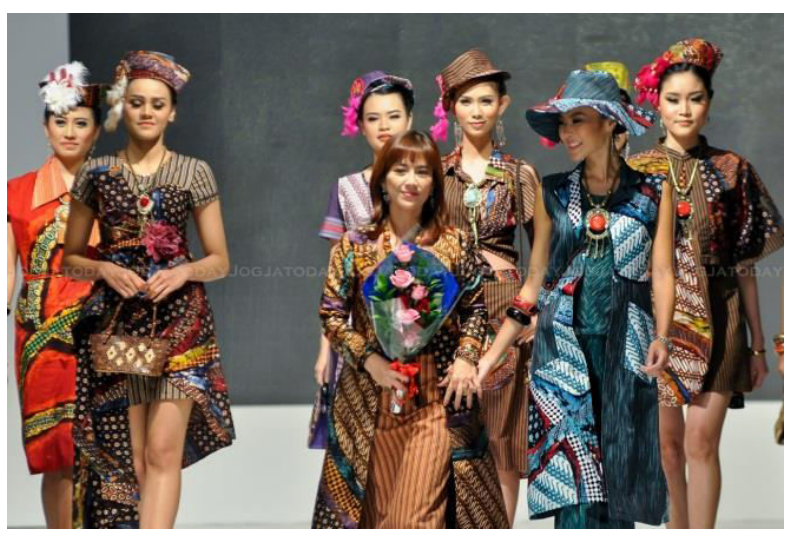

Produk Fashion Batik Kontemporer Motif, Jogya Fashion Week 2016

Meskipun dalam perkembangannya meningkatnya nilai ekonomi batik telah banyak andil dalam penggalian budaya, mengatasi pengangguran, pengembangan ekonomi perajin, dan pengembangan batik kita. Perkembangan batik modern di Indonesia.Pengembangan desain batik modern di Indonesia seperti yang diungkapkan Kuntjoroningrat dapat dikategorikan menjadi tiga kelompok besar.
1. Karya desain yang diciptakan sebagai tuntutan masyarakat yang berpikiran modern, baik secara mentalitas maupun tindakannya.

2. Karya desain yang mengadaptasi dan menggunakan berbagai kebudayaan asing yang telah modern tanpa harus "menjadi asing" atauberciri asing.

3. Karya desain yang semata mata meniru gaya orang asing tanpa diimbangi oleh proses berpikir dan mentalitas modern.

Kekawatiran banyak muncul dari tokoh masyarakat, misalnya Sanusi Pane (1935) menyampaikan kekawatirannya terhadap bahasa daerah sebagai kesenian yang hanya diminati oleh generasi tua dan kurang menarik bagi generasi muda. Hal ini merupakan suatu kekeliruan dalam sistem pendidikan nasional. Pendidikan konvensional tanpa kebaharuan akan kehilangan jiwanya, dan akan tergeser digantikan oleh peradaban asing. Sejalan dengan keprihatinan itu, keberadaan kesenian tradisional kita memiliki nasib yang sama. Generasi muda mulai tidak mengenal budaya tradisinya sendiri. Hadirnya perkembangan pariwisata di era sekarang ini walaupun banyak yang pro dan kontra terhadap keberadaan seni tradisi Indonesia.

Pariwisata salah satu bentukpengenalan budaya nusantra secara global telah terbukti cukup merubah keberadaan seni batik kita. Pariwisata lebih banyak dilandasi motif ekonomi daripada unsur yang lain. 


\section{KESIMPULAN}

Negara berkembang seperti Indonesia dalam era global ini memiliki ketergantungan cukup besar terhadap negara maju. Begitu ada goncangan di negara maju berdampak terhadap keamanan, politik, dan ekonomi. Batik yang mampu eksis, paling tidak ditinjau dari aspek ekonomi adalah batik yang sudah memasuki pasar ekspor atau global.

Suatu keberuntungan yang masih dapat kita syukuri bersama pada era yang penuh dengan kontradisi, ketidak pastian, ketergantungan, dan persaingan masih banyak pencipta kesenian khususnya batik tradisional bermunculan kembali dalam upaya pelestarian dan pengenalan budaya sendiri kepada generasi penerusnya. Disisi lain banyak pencipta kesenian tradisional dapat lebih kreatif dapat membaca jaman dan mampu hidup kembali dari berolah seninya untuk memenuhi kebutuhan masyarakatnya sendiri maupun untuk memenuhi kebutuhan orang banyak dalam era kesejagatan ini.

Kreativitas dan keuletan desainer /pembatik untuk selalu mencari dan menemukan sesuatu yang baru menghadapi tantangan ke depan yang lebih baik. Terus mencariinovasi untuk pengembangan kreativitas berkesenian dalam kemajemukan budaya ini. Hanya orang yang mau berpikir, berpelilaku, dan inovatif yang mampu beradaptasi, bertahan dan berkembang dalam percaturan global sekarang ini.

Kesenian kita tidak boleh hanya sebagai objek kesenian global melainkan harus dapat menjadi subjek kesenian yang dapat menentukan dirinya sendiri. Cara menjadi subjek adalah kemampuan menciptakanunggulan, karya besar yang sanggup memberi sumbangan kepada kesenian dunia. Suatu karya seperti kiprah leluhur kita menciptakan karya-karya kesenian tradisional adiluhung yang tidak lekang oleh zaman. Mampukah desainer batik kita menjawab pertanyaan itu. Kita harus bisa buktikan bersama desainer batik bahwa kita bisa.Pondasi pengetahuan dasar yang kuat, keteguhan akan nilai dan norma kehidupan berbangsa dan berbudaya yang dipegang yang mampu membuat tetap tegardan mampu bersaing dalam kehidupan bersama. Globalisasi adalah sebuah tantangan masa depan yang harus dihadapi dengan waspada agar tetap punya nilai dan identitas sebagai bangsa yang berbudaya. Desain batik nusantara adalah batik yang diciptakan berdasarkan norma, nilai, tradisi, dan inovasi yang berkembang di Nusantara. Desain batik itulah yang dapat dikenali sebagai produk tekstil yang bernuansa Indonesia.

\section{DAFTAR PUSTAKA}

Alisjahbana, S. Takdir.

1985.Seni dan Sastra di Tengah-tengah Pergolakan Masyarakat dan Kebudayaan, Jakarta: Dian Rakyat.

Anggraini, Nenny.

2008. “Industri Kreatif”, Jurnal ekonomi

Desember 2008 Volume XIII No. 3 hal. 
Hendropuspito OC, D.

1989. Sosiologi Sistematik. Yogyakarta: Kanisius.

Koentjaraningrat.

1994.Kebudayaan Jawa. Jakarta: Balai Pustaka.

Pidarta, Made.

1997. Landasan Kependidikan. Jakarta: Rineka Cipta.

Rohidi, Rohendi Tjetjep.

2000 , Kesenian dalam Pendekatan Kebudayaan.

Bandung: STISI Press.

Soedarso SP.

1991. Beberapa Catanan tentang Kesenian Kita.

Yogyakarta: BPISI

Soedarso SP.

2000. Perkembangan Seni Rupa Modern.

Yogyakarta: BP ISI 